\title{
A Grey-TOPSIS Approach to Minimize COVID-19 Transmission for the Betterment of Public-Health in the Indian Context
}

\author{
Debesh Mishra, SAGE University, Bhopal, India \\ (iD) https://orcid.org/0000-0003-2665-1365 \\ Suchismita Satapathy, KIIT University (Deemed), Bhubaneswar, India \\ (iD) https://orcid.org/0000-0002-4805-1793 \\ V. K. Jain, SAGE University, Bhopal, India
}

\begin{abstract}
In view of diminishing the transmission of the coronavirus pandemic (COVID-19) in the community, an essential intervention strategy has been the consideration of public health measures. However, at the present scenario, these measures can be considered as the only available tools for mitigation of this virus impact. An attempt was made in this study with the use of grey technique for order of preference by similarity to ideal solution (Grey-TOPSIS) method for prioritizing the precautionary measures for the public health in order to enable taking appropriate steps by the general public of India to protect them from virus transmission.
\end{abstract}

\section{KEYWORDS}

Coronavirus, COVID-19, Grey-TOPSIS, India, Knowledge, Public Health

\section{INTRODUCTION}

There has been an impressive pace in the progress of the Indian health-care industry (Sisodia and Agrawal, 2019). Moreover, the healthcare-system is a real example for any distributed collaborativesystem for the improvement in the healthcare of patients (Barhoun et al., 2019). Infectious diseases have become as one of the major public-health problem in India. Occasionally, it is seen of attaining epidemic-proportion by some of the infectious-diseases, even-though many of these diseases are found to be wide-spread like flu and malaria. A sudden with an increasing number of disease-cases is reported in case of an epidemic in excess of normal expectation in a community, which are usually public-health-emergencies that disrupt the routine health services. These include a variety of viral infectious-disease like dengue, polio, measles, mengitis, and typhoid-fevers with some bacteria-based infectious-disease like cholera, diarrheoa, etc. Some of the significant factors that cause in epidemic have been reported as lack of clean as well as hygienic drinking-waters, contaminations of sources of drinking-water, lacking of awareness related to insanitation, unhygienic-food, over-crowds, and biological-conditions in addition to ecological-factors. 
For the control measures of epidemic in addition to treatment of patients, a higher cost is incurred that is associated with the negative impacts on both domestic as well as international levels. The epidemics occurrences are due to several factors allied to microorganisms \& environment. Furthermore, as a consequence of prevailing of these factors, a number of developing countries like India have been affected by epidemics frequently followed by a higher mortality rate, and thus adversely impacting on the normal health of public with their economy-levels. Therefore, the present study aimed at exploring the preventive measures through general guidelines for the betterment and safety of public-health from the transmission of COVID-19 viruses in India, which has been recently increasing throughout the world.

\subsection{Related Literature}

A number of studies and researches have been done on the infectious-diseases through some kind of viruses. For instance, the mitigation approaches have been described in a study for combating ñu-pandemic at different levels at the nation (Chawla et al., 2009). Bats are considered to be the "natural-reservoir" for different highly pathogenic-viruses like coronavirus. A total of 183 and 236 children who were hospitalized with acute-encephalitis like syndrome and respiratory-tract infections were considered for exploring of the cytokine-expression profiles in them ( $\mathrm{Li}$ et al., 2016). When compared to adult-bats, the coronavirus related infections in addition to shedding were found to be more with younger (Wacharapluesadee et al., 2018). The transmissibility in addition to severity of "Middle East Respiratory Syndrome (MERS)" infection was reported with differences in outbreak provinces as well as patients' characteristics (Park et al., 2018). In November 2002, the identification of first typical pneumonia through "SARS-CoV" was made in Guangdong of China, and further the infection was quickly exposed to Beijing, Singapore, Canada, Hong-Kong, and Vietnam in March 2003 as a highly infectious-disease with 'respiratory-droplets' as major routes for its transmission (Hui and Zumla, 2019). The "coronavirus-envelope (E) protein" is a smaller and integral membrane protein, which is associated with a number of 'virus-life-cycle' aspects like assembling, budding, pathogenesis and formations in envelope (Schoeman and Fielding, 2019). Hierlihy et al. (2019) have reported Based on an analysis, it was reported of mitigating measures for the 'mosquito-borne virus' like Chikungunya to be categorized into six-types such as "insecticide uses, public-education, behavioural protective measures, blood as well as blood-products' control, biological-vector control, and quarantine of infected-persons", respectively. Salamatbakhsh et al. (2019) have made an assessment of the worldwide premature-mortality burdens due to MERS with the use of available data from the website of WHO regarding the report of " 1789 MERS-patients between 23/09/2012 and 17/05/2019 in 'Saudi-Arabia'. In majority of cases, there was reporting of mild-illness as well as fever-symptoms with COVID-19, and cough was the most common symptoms. For 'over-aged persons or with comorbid conditions', the occurrences of severe and fatal outcome tend to be more (Sun et al., 2020; WHO, 2020a). Li et al. (2020) have stated about the neurological-signs found with some COVID-19 patients as headache, nausea as well as vomiting. For the COVID-19 patients with acute respiratoryfailures, the invasions in the central-nervous system have been reported to be partially responsible. According to WHO (2020b), the present methodology of treatment for COVID-19 cases focuses mainly on early-recognition, isolations, suitable controlling measures for infections in addition to supportive-care provisions. A number of 'clinical-trials' have been made to evaluate the therapeuticagents for the confirmed or suspected 'SARS-CoV-2' infections with no specific antiviral-treatment evidences (Harrison, 2020). Although large numbers of research-efforts are being carried out, but the appearance of new diseases is still a source of substantial-uncertainty. A single worker was considered at the market of Wuhan (China) with a severe respiratory-syndrome, who was admitted to the central-hospital on 26/12/2019, and that patient was further reported to be coronavirus affected in close relation to a group of "Severe Acute-Respiratory-Syndrome (SARS)" like coronavirus (e.g., "genus Beta coronavirus, subgenus Sarbecovirus" that were found previously in bats (Wu et al., 2020). Powerful methodologies based on network have been suggested for rapidly identifying 
the potential-drugs for '2019-nCoV/SARS-CoV-2'. The direct-transmissions of "2019-nCoV" from 'person-to-person' include contact-transmission, sneezes, cough, and droplet-inhalations, which can also be transmitted through the saliva in addition to oral-routes (Zhou et al., 2020). By considering the dental-professionals, Peng et al. (2020) have recommend of control measures during dentalpractices for preventing the infection transmission from person-to-person in 'dental-clinics as well as hospitals'. Gudi and Tiwari (2020) have elaborated about the captured consciousness throughout the world in a short-span by the novel coronavirus that has been significantly affecting the human dayto-day life activities and emerged as a public-health emergency. Based on the suitability of respective clinical settings, the ophthalmologists need to work closely with local 'infection-control teams' for implementing infection-control measures with the aim to minimize the transmission of COVID-19 viruses (Lai et al., 2020). Fisher and Heymann (2020) have concluded that the species SARS like coronaviruses to be responsible for 'COVID-19 and SARS-CoV-2', which was found to be slightlylarger than 'influenza, SARS and MERS viruses at $125 \mathrm{~nm}$ '. Chen et al. (2020) have made an attempt in the development of a mathematical-model for calculating the transmissibility of coronavirus with the help of a 'Bats-Hosts Reservoir-People transmission network-model' and by further simplifying the model as 'Reservoir-People transmission network-model'. They found a higher transmission of SARS-CoV-2 as compared to the MERS in the "Middle-East Countries", but transmission of MERS in the "Republic of Korea" was higher. For providing 'an innovative-approach to virology-teaching', a 'slide-microscope kit' was developed that helped in exploring giant 'virus-particles' along with some aspects of 'animal-virus interaction with cell-lines'. Further, the kit was used in 'practical-virology classes' for the "Biological-Sciences" course at UFMG in Brazil (de Souza et al., 2020).

Risk has been identified as the most critical element to be associated with any economic decisionmaking (Galli and Battiloro, 2019). Many approvals are required for every decision in the public-sector that greatly hinders economic-decisions in addition to decision-making (Galli, 2020a), and an improved working conditions lead to overall success of any organization within the highly contested-market (Galli, 2020b). Moreover, the applications of 'multi-criteria decision making (MCDM)' methods have been increasing for various significant areas. For instance, some of the MCDM methods include: "data envelopment analysis (DEA)", " analytic hierarchy process (AHP)", "preference-ranking organizationmethod for enrichment-evaluations (PROMETHEE)", "decision-making trial and evaluation laboratory (DEMATEL)", "technique for order of preference by similarity to ideal solution (TOPSIS)", and so on (Chaharsooghi and Ashrafi, 2014; Wu, 2007). As the decision-makers' judgments are sometimes uncertain and also, remain undefined with certainty. Therefore, it becomes difficulty in making the decision process. Different researchers have also integrated different methodologies with a view to solve vague-problems in "non-deterministic social, environmental as well as economical areas" (Kuo et al., 2008; Li et al., 2007; Zhang et al., 2005). The superiority of 'Grey theory' has been reported in case of uncertain-information situations that help in studying human-judgments with uncertainty as well as ambiguity (Li et al., 2007). Shih et al. (2007) have made an investigation on the extension of TOPSIS for a 'group-decision environment' in the tea-industry and also, developed a grey based TOPSIS method. For the selection of best-suppliers in MCDM approach, an integrated 'grey theory and TOPSIS' model was suggested (Jadidi et al., 2008). Similarly, in order to select the suitable 'flexiblesystem' in implementing "mass-customization strategies", a MCDM method based on grey theory and fuzzy-TOPSIS was suggested (Mishra et al., 2013). Aliakbarzadeh and Tabriz (2014) have applied "Fuzzy AHP and TOPSIS" for evaluating the performances in addition to the ranking of different branches banks. The fuzzy-TOPSIS was proposed in a study for the improvement of the supply-chain management process of the 'food-industries' (Roghanian et al., 2014). The 'Grey-TOPSIS' approach was used in a study for the measurement and ranking of the value-chain performances of the 'teaprocessing firms' (Nyaoga et al., 2016). Srivastawa et al. (2017) have evaluated the performances of ten gear-materials on the basis of four selective-criteria by the use of 'Grey-TOPSIS' method and then, they validated the result by "Grey-Complex proportional assessment (COPRAS-G)" method. Rahpeyma and Zarei (2018) have integrated two techniques, such as "Quality Function Deployment 
(QFD)" and "The Technique for Order of Preference by Similarity to Ideal Solution (TOPSIS)" for the evaluation and ranking of suppliers based on their merits. The problems of the existing 'coordinatedTOPSIS' were elaborated and a novel 'coordinated-TOPSIS' was proposed in consideration of the co-efficient of variation for avoiding the limitations in the existing 'coordinated-TOPSIS' (Chen, 2019). Fatma et al. (2020) have proposed an approach by combining the graphical-representation that was provided by Petri-nets and fuzzy-logic for modelling and failure analysis. Although, a number of researches and initiatives have been under taken by different countries in view of the pandemic COVID-19 virus transmission and disease prevention, but still most of the general public in India are unaware about the primary preventive measures and precautions to protect them from the ill-effects of these viruses. Therefore, the main aim of this study was to prioritize the preventive measures against COVID-19 viruses' infectious-diseases under "Grey-TOPSIS" multi-criteria environment, which has been reported to be very suitable method for solving the 'group decision-making problems' in an environment with un-certainty (Li et al., 2006; 2007).

\section{METHODOLOGY OF RESEARCH}

Combination of the sentiment-analysis "Naïve Bayes technique" in the natural language-processing as well as personality-insights pre learning-stage, and with the addition of feedback help to provide higher accuracies as compared to the traditional sentiment-analysis techniques (Adl and Elfergany, 2020). Apart from the sentiments of individuals, their knowledge as well as awareness helps in providing an in-depth study on some particular context. In this study, a total of 232 individuals were considered to collect their knowledge as well as awareness about the recent epidemic coronavirus in Indian context. Between the age group of 30 to 70 years, a randomly choosing and selection of the participants was made from the state of Odisha (India). Further, on the basis of the opinions of five-experts from the health-care field, the precautionary measures for COVID-19 were identified as the alternatives for three different criteria for a sustainable public-health such as environmental, social and economic criteria. Then, the "Grey-TOPSIS" method was applied for evaluating as well as ranking of the preventive-measures as alternatives to fight against the COVID-19 viruses in view of the betterment of general public in India. The steps followed in this study were as illustrated in Figure 1.

\subsection{Steps in "Grey-TOPSIS" Method}

At first, the linguistic-values expressed in grey-numbers were applied for the assessment of weights as well as ratings of performance evaluation-criteria. Secondly, the grey-numbers criteria importanceweights were de-greyed and then, normalized. And finally, TOPSIS multi-model based on fuzzy-set theory was expressed, and fuzzy positive as well as negative ideal-solutions were used for determining the closeness ideal-solution for each performance and then, they were ranked accordingly.

This method has been reported to be very suitable to solve the 'group decision-making problems' in an environment with un-certainty. It was assumed that $\mathrm{P}=\mathrm{P}_{1}, \mathrm{P}_{2}, \ldots, \mathrm{P}_{\mathrm{m}}$ were a discrete-set of ' $\mathrm{m}$ ' possible-alternatives as precautionary measures for COVID-19, and $C_{R_{2}}=C_{R 1}, C_{R 2}, \ldots ., C_{R n}$ as a set of ' $\mathrm{n}$ ' criterion. The criterions were additively-independent, and $\ddot{\mathrm{A} w}=\ddot{\mathrm{A}} \mathrm{w}_{1}, \mathrm{Aw}_{2}, \ldots, \ddot{A}_{\mathrm{n}}$ was the vector of criteria-weights. In this study, the criteria-weights as well as ratings of alternatives were considered as linguistic-variables (Li et al., 2006; 2007).

The linguistic-variables can be expressed in grey-numbers by "1 to 7 scale" as illustrated in Table 1 . Moreover, the criteria-ratings ( $\ddot{\mathrm{A} G}$ ) can also be expressed in grey-numbers by " 1 to 7 scale" as illustrated in Table 2.

The steps followed for the "Grey-TOPSIS" method were as following: 
Figure 1. Steps followed

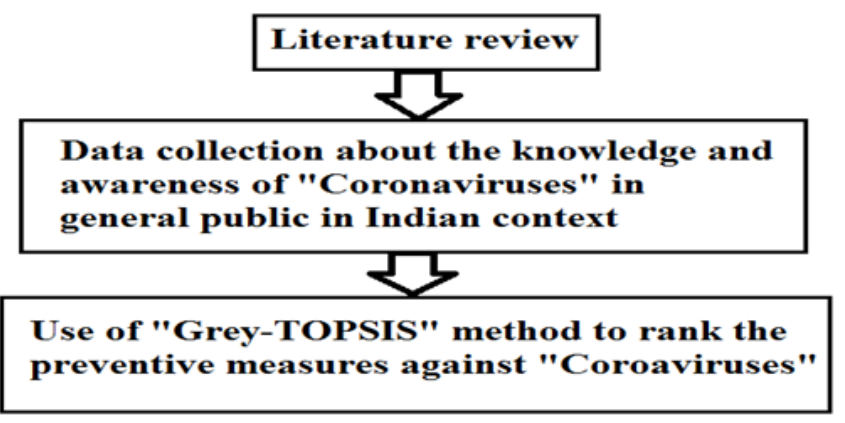

Table 1. The scale of criteria-weights (Äw)

\begin{tabular}{|l|l|}
\hline Scale & $\ddot{\text { Äw }}$ \\
\hline Very-low (VL) & {$[0.0,0.1]$} \\
\hline Low (VL) & {$[0.1,0.3]$} \\
\hline Medium-low (ML) & {$[0.3,0.4]$} \\
\hline Medium (M) & {$[0.4,0.5]$} \\
\hline Medium-high (MH) & {$[0.5,0.6]$} \\
\hline High (H) & {$[0.6,0.9]$} \\
\hline Very-high $(\mathrm{VH})$ & {$[0.9,1.0]$} \\
\hline
\end{tabular}

Table 2. The scale of criteria-ratings (ÄG)

\begin{tabular}{|l|l|}
\hline Scale & $\ddot{\text { AG }}$ \\
\hline Very-poor (VP) & {$[0,1]$} \\
\hline Poor (P) & {$[1,3]$} \\
\hline Medium-poor (MP) & {$[3,4]$} \\
\hline Fair (F) & {$[4,5]$} \\
\hline Medium-good (MG) & {$[5,6]$} \\
\hline Good (G) & {$[6,9]$} \\
\hline Very-good (VG) & {$[9,10]$} \\
\hline
\end{tabular}

Step 1: Forming a committee of decision-makers and identifying the criteria-weights of alternatives. By assuming of a decision-group having $\mathrm{K}$ persons, the criteria-weight of criteria $\mathrm{C}_{\mathrm{Rj}}$ can be calculated as:

$$
\otimes w_{j}=\frac{1}{K}\left(\otimes w_{j}^{1}+\otimes w_{j}^{2}+\ldots+\otimes w_{j}^{K}\right)
$$


Where, $\otimes w_{j}^{K}(\mathrm{j}=1,2, \ldots, \mathrm{n})$ represents the criteria-weight of $\mathrm{K}^{\text {th }}$ decision-makers.

Step 2: Using the linguistic-variables for the ratings to make the criteria rating-value. Then, the rating-values can be calculated as:

$$
\otimes G_{i j}=\frac{1}{K}\left(\otimes G_{i j}^{1}+\otimes G_{i j}^{2}+\ldots+\otimes G_{i j}^{K}\right)
$$

Where, $(i=1,2, \ldots, m ; j=1,2, \ldots, n)$ was the criteria rating-value of $\mathrm{K}^{\text {th }}$ decision-makers.

Step 3: Establishing the grey decision-matrix as:

$$
D=\left[\begin{array}{cccc}
\otimes G_{11} & \otimes G_{12} & \ldots & \otimes G_{1 n} \\
\otimes G_{21} & \otimes G_{22} & \cdots & \otimes G_{2 n} \\
\vdots & \vdots & \ddots & \vdots \\
\otimes G_{m 1} & \otimes G_{m 2} & \cdots & \otimes G_{m n}
\end{array}\right]
$$

Where, $\ddot{A}$ were linguistic-variables based on the grey-number.

Step 4: Normalizing the grey decision-matrix as:

$$
D=\left[\begin{array}{cccc}
\otimes G_{11} & \otimes G_{12} & \cdots & \otimes G_{1 n} \\
\otimes G_{21} & \otimes G_{21} & \cdots & \otimes G_{2 n} \\
\vdots & \vdots & \ddots & \vdots \\
\otimes G_{m 1} & \otimes G_{m 2} & \cdots & \otimes G_{m n}
\end{array}\right]
$$

Where, for a benefit-criterion, was expressed as:

$$
G_{i j}=, G_{j}^{\max }=\max _{1 \leq i \leq m}\left(\bar{G}_{i j}\right)
$$

Where, for a cost-criterion, $\otimes G_{i j}$ was expressed as:

$$
G_{i j}=, G_{j}^{\min }=\min _{1 \leq i \leq m}
$$

The normalization method mentioned above was to preserve the property that the ranges of the normalized grey-number belonged to $[0,1]$. 
Step 5: Establishing the weighted normalized grey decision-matrix. Considering the different importance of each criterion, the weighted normalized grey decision-matrix can be established as:

$D=\left[\begin{array}{cccc}\otimes V_{11} & \otimes V_{12} & \cdots & \otimes V_{1 n} \\ \otimes V_{21} & \otimes V_{22} & \cdots & \otimes V_{2 n} \\ \vdots & \vdots & \ddots & \vdots \\ \otimes V_{m 1} & \otimes V_{m 2} & \cdots & \otimes V_{m n}\end{array}\right]$

$\otimes V_{i j} \otimes G_{i j} \times \otimes w_{j}$

Step 6: Making the ideal alternative as a referential alternative. For ' $m$ ' possible alternatives set $S$ $=\left[S_{1}, S_{2}, \ldots ., S_{m}\right]$, the ideal referential alternative $\left.S_{\max }=\right]$ can be obtained by:

$S^{\max }=$

Step 7: Calculation of the grey possibility-degree between compared alternatives set $\mathrm{S}=\left[S_{1}\right.$, $S_{2}, \ldots ., S_{m}$, and ideal referential alternative $S^{\max }$.

$\mathrm{P}\left[S_{i} \leq S^{\max }\right]=\frac{1}{n} \sum_{j=1}^{n} P\left[\otimes V_{i j} \leq \otimes G_{j}^{\max }\right]$

Step 8: Ranking of the order of set alternatives. When, $\mathrm{P}\left[S_{i} \leq S^{\max }\right]$ will be smaller, the ranking order of $S_{i}$ will be better. Otherwise, the ranking order will be worse.

According to the above procedures, the ranking order of all alternatives can be determined and the best among the set of feasible alternatives can be selected.

\subsection{Selection of criteria and alternatives}

Moreover, the precautionary measures against COVID-19 viruses and its' transmission to the public were considered as six alternatives i.e. $\mathrm{P}_{1}, \mathrm{P}_{2}, \mathrm{P}_{3}, \mathrm{P}_{4}, \mathrm{P}_{5}$, and $\mathrm{P}_{6}$, as evaluated by the experts under three-criteria for a sustainable public-health such as "Environmental $\left(\mathrm{C}_{\mathrm{EV}}\right)$, Social $\left(\mathrm{C}_{\mathrm{SO}}\right), \&$ Economic $\left(\mathrm{C}_{\mathrm{EC}}\right)$ ", respectively (Table 3).

\section{RESULTS AND DISCUSSION}

Based on the socio-demographic characteristics and the knowledge level about the infectious-diseases among the participants (Table 4), it was observed that the number of male and female participants were $122(52.58 \%)$ and $110(47.41 \%)$ out of a total of 232 numbers of participants. However, the responded participants were more between the age group of 30 to 50 years $(50.86 \%)$ with education of primary to high school to be $47.84 \%$. The number of participants having previous knowledge about epidemic infections was 208 (89.65\%), and the number of participants taking precautionary measures 
Table 3. Selection of criteria and alternatives (precautions against COVID-19)

\begin{tabular}{|c|c|c|}
\hline Criteria & $\begin{array}{l}\text { Precautionary- } \\
\text { measures }\end{array}$ & Descriptions \\
\hline Environmental $\left(\mathrm{C}_{\mathrm{EV}}\right)$ & $\begin{array}{l}\text { Environmental } \\
\text { cleanliness and } \\
\text { ventilation }\left(\mathrm{P}_{1}\right)\end{array}$ & $\begin{array}{l}\text { In order to prevent the transmission of COVID-19, there } \\
\text { is a requirement of routine cleaning practice of frequently } \\
\text { used objects as well as surfaces to help in mitigating } \\
\text { the inflectional-risks of people. As the viruses causing } \\
\text { COVID-19 has the potential to survive up to several days } \\
\text { in the environment. Thus, the cleanliness of frequently } \\
\text { touched surfaces can help in killing the viruses and making } \\
\text { no possible infected people. The cleanliness of high-traffic } \\
\text { public-spaces should follow a regular cleaning practice such } \\
\text { as airports, malls, public-transportation, etc. And the items } \\
\text { that are un-easy to clean need to be removed like magazines, } \\
\text { newspapers, stuffed-toys, etc. } \\
\text { Moreover, it has been observed through different studies that } \\
\text { increased ventilation reduces the influenza transmissions. }\end{array}$ \\
\hline \multirow[t]{3}{*}{ Social $\left(\mathrm{C}_{\mathrm{so}}\right)$} & Social-distancing $\left(\mathrm{P}_{2}\right)$ & $\begin{array}{l}\text { Social-distancing measures are essential in order to } \\
\text { minimize close-contacts with others in the community that } \\
\text { include quarantine as well as self-isolation at the individual- } \\
\text { level in addition to other community based-approaches such } \\
\text { as avoidance of crowding and public or mass gathering. }\end{array}$ \\
\hline & Respiratory-manners $\left(\mathrm{P}_{3}\right)$ & $\begin{array}{l}\text { Respiratory-manners are the combination of measures for } \\
\text { minimizing the dispersion of large-particle respiratory- } \\
\text { droplets during talking, coughing and sneezing of ill- } \\
\text { persons for reduction in virus transmission. }\end{array}$ \\
\hline & Self-observations $\left(\mathrm{P}_{4}\right)$ & $\begin{array}{l}\text { Self-observations are essential for the individuals who are } \\
\text { potentially exposed to the COVID-19 virus. If any of the } \\
\text { infection related symptoms appear, then the individual } \\
\text { should follow the recommended public-health measures at } \\
\text { home as well as to seek medical-care on the basis of severity } \\
\text { of symptoms. }\end{array}$ \\
\hline \multirow[t]{2}{*}{ Economic $\left(\mathrm{C}_{\mathrm{EC}}\right)$} & Hand-hygiene $\left(\mathrm{P}_{5}\right)$ & $\begin{array}{l}\text { Hand-hygiene include washing of hands with soaps\& water, } \\
\text { and/or sanitizing hand with tissues or gels or alcoholic } \\
\text { solutions in order to maintain clean fingernails as well as } \\
\text { hands. The hands should be cleaned frequently with soap } \\
\text { \& water for at least } 15-20 \text { seconds keeping the following in } \\
\text { mind: } \\
\text { - Before and after preparation of foods; } \\
\text { - Before and after having foods; } \\
\text { - After use of toilets; } \\
\text { - After cough/sneeze into a tissue; } \\
\text { - Before and after use of surgical masks; } \\
\text { - After the removal of gloves; } \\
\text { - After usage of body fluid-dirtied wastes or laundry; } \\
\text { - To clean dirty hands. } \\
\text { Moreover, it should be avoided to touch one's eyes, nose, } \\
\text { and mouth with un-washed \& dirty hands. Therefore, the } \\
\text { government and the competent authorities need to provide } \\
\text { all these necessities at subsidized costs to the general public } \\
\text { to facilitate a cleaner environment. }\end{array}$ \\
\hline & $\begin{array}{l}\text { Utilization of protective- } \\
\text { masks }\left(\mathrm{P}_{6}\right)\end{array}$ & $\begin{array}{l}\text { Utilization of protective-masks provide physical barrier to } \\
\text { individuals to prevent the virus transmission. }\end{array}$ \\
\hline
\end{tabular}


Table 4. Socio-demographic characteristics and knowledge level of participants $(n=232)$

\begin{tabular}{|l|l|l|}
\hline Characteristics & Parameter & Number of responses (\%) \\
\hline \multirow{3}{*}{ Gender } & Male & $122(52.58 \%)$ \\
\cline { 2 - 3 } & Female & $110(47.41 \%)$ \\
\hline \multirow{2}{*}{ Age (Years) } & $30-50$ & $118(50.86 \%)$ \\
\cline { 2 - 3 } & $51-70$ & $114(49.13 \%)$ \\
\hline \multirow{5}{*}{ Education } & Nil & $51(21.98 \%)$ \\
\cline { 2 - 3 } & Under primary & $38(16.38 \%)$ \\
\cline { 2 - 3 } & Primary to high school & $111(47.84 \%)$ \\
\cline { 2 - 3 } & Above high school & $32(13.79 \%)$ \\
\hline \multirow{2}{*}{$\begin{array}{l}\text { Previous knowledge about epidemic infections. } \\
\text { Any precautionary measures taking against }\end{array}$} & No & $24(10.34 \%)$ \\
\cline { 2 - 3 } COVID-19. & Yes & $208(89.65 \%)$ \\
\cline { 2 - 3 } & No & $52(22.41 \%)$ \\
\hline \multirow{2}{*}{\begin{tabular}{l} 
Any friends or relatives infected of COVID-19. \\
\cline { 2 - 3 }
\end{tabular}} & No & $21(90(77.58 \%)$ \\
\cline { 2 - 3 } & Yes & $211(90.94 \%)$ \\
\hline
\end{tabular}

against COVID-19 was 180 (77.58\%), respectively. While, a total of 21 participants (9.05\%) reported of their friends or relatives to be infected of COVID-19.

After assigning the weight values (W) to different criteria (C) for a sustainable public-health in Indian context, the integrated-matrix was obtained for all the six alternatives as the precautionary measures against COVID-19 (Table 5), which was further followed by the normalized-matrix (Table 6) and weighted normalized-matrix (Table 7), respectively.

\section{Table 5. Integrated-matrix}

\begin{tabular}{|c|c|c|c|c|c|c|}
\hline \multirow{3}{*}{$\begin{array}{l}\text { Precautionary- } \\
\text { measures }\end{array}$} & \multicolumn{2}{|l|}{$\mathbf{W}_{\mathrm{EV}}$} & \multicolumn{2}{|l|}{$\mathbf{w}_{\text {so }}$} & \multicolumn{2}{|l|}{$\mathbf{W}_{\mathrm{EC}}$} \\
\hline & 0.67 & 0.95 & 0.75 & 0.95 & 0.65 & 0.75 \\
\hline & \multicolumn{2}{|l|}{$\mathrm{C}_{\mathrm{EV}}$} & \multicolumn{2}{|l|}{$\mathrm{C}_{\mathrm{so}}$} & \multicolumn{2}{|l|}{$\mathbf{C}_{\mathrm{EC}}$} \\
\hline $\mathrm{P}_{1}$ & 4.600 & 6.600 & 4.400 & 6.000 & 4.400 & 6.000 \\
\hline $\mathrm{P}_{2}$ & 4.000 & 5.200 & 4.400 & 6.000 & 4.600 & 6.600 \\
\hline $\mathrm{P}_{3}$ & 3.800 & 5.000 & 2.600 & 3.600 & 4.200 & 5.800 \\
\hline $\mathrm{P}_{4}$ & 3.600 & 4.400 & 1.600 & 2.800 & 4.400 & 6.000 \\
\hline $\mathrm{P}_{5}$ & 3.600 & 4.400 & 2.000 & 3.000 & 3.600 & 4.400 \\
\hline $\mathrm{P}_{6}$ & 4.200 & 5.400 & 1.600 & 2.800 & 3.400 & 4.200 \\
\hline MAX & \multicolumn{2}{|l|}{6.600} & \multicolumn{2}{|l|}{6.000} & \multicolumn{2}{|l|}{6.600} \\
\hline MIN & \multicolumn{2}{|l|}{3.600} & \multicolumn{2}{|l|}{1.600} & \multicolumn{2}{|l|}{3.400} \\
\hline
\end{tabular}

${ }^{*} \mathrm{C}_{\mathrm{EV}}=$ Environmental criteria, $\mathrm{C}_{\mathrm{SO}}=$ Social criteria, $\mathrm{C}_{\mathrm{EC}}=$ Economic criteria, $\mathrm{W}_{\mathrm{EV}}=$ Weight values of environmental criteria, $\mathrm{W}_{\mathrm{SO}}=$ Weight values of social criteria, and $\mathrm{W}_{\mathrm{EC}}=$ Weight values of economic criteria. 
Table 6. Normalized-matrix

\begin{tabular}{|l|l|l|l|l|l|l|l|}
\hline \multirow{2}{*}{$\begin{array}{l}\text { Precautionary- } \\
\text { measures }\end{array}$} & \multicolumn{2}{|l|}{$\mathbf{W}_{\mathbf{E V}}$} & \multicolumn{2}{l}{$\mathbf{W}_{\text {So }}$} & \multicolumn{2}{l|}{$\mathbf{W}_{\text {EC }}$} \\
\cline { 2 - 8 } & $\mathbf{0 . 6 7}$ & $\mathbf{0 . 9 5}$ & $\mathbf{0 . 7 5}$ & $\mathbf{0 . 9 5}$ & $\mathbf{0 . 6 5}$ & $\mathbf{0 . 7 5}$ \\
\cline { 2 - 8 } & $\mathbf{C}_{\mathbf{E V}}$ & \multicolumn{2}{|l|}{$\mathbf{C}_{\text {SO }}$} & \multicolumn{2}{l|}{$\mathbf{C}_{\text {EC }}$} \\
\hline $\mathrm{P}_{1}$ & 0.545 & 0.783 & 0.267 & 0.364 & 0.567 & 0.773 \\
\hline $\mathrm{P}_{2}$ & 0.692 & 0.900 & 0.267 & 0.364 & 0.515 & 0.739 \\
\hline $\mathrm{P}_{3}$ & 0.720 & 0.947 & 0.444 & 0.615 & 0.586 & 0.810 \\
\hline $\mathrm{P}_{4}$ & 0.818 & 1 & 0.571 & 1 & 0.567 & 0.773 \\
\hline $\mathrm{P}_{5}$ & 0.818 & 1 & 0.533 & 0.800 & 0.773 & 0.944 \\
\hline $\mathrm{P}_{6}$ & 0.667 & 0.857 & 0.571 & 1 & 0.810 & 1 \\
\hline
\end{tabular}

Table 7. Weighted normalized-matrix

\begin{tabular}{|l|l|l|l|l|l|l|}
\hline $\begin{array}{l}\text { Precautionary- } \\
\text { measures }\end{array}$ & \multicolumn{2}{l}{$\mathbf{C}_{\text {EV }}$} & \multicolumn{2}{l|}{$\mathbf{C}_{\text {So }}$} & \multicolumn{2}{l|}{$\mathbf{C}_{\text {EC }}$} \\
\hline $\mathrm{P}_{1}$ & 0.365 & 0.743 & 0.200 & 0.345 & 0.368 & 0.580 \\
\hline $\mathrm{P}_{2}$ & 0.464 & 0.855 & 0.200 & 0.345 & 0.335 & 0.554 \\
\hline $\mathrm{P}_{3}$ & 0.482 & 0.900 & 0.333 & 0.585 & 0.381 & 0.607 \\
\hline $\mathrm{P}_{4}$ & 0.548 & 0.950 & 0.429 & 0.950 & 0.368 & 0.580 \\
\hline $\mathrm{P}_{5}$ & 0.548 & 0.950 & 0.400 & 0.760 & 0.502 & 0.708 \\
\hline $\mathrm{P}_{6}$ & 0.447 & 0.814 & 0.429 & 0.950 & 0.526 & 0.750 \\
\hline $\mathrm{S}^{+}$ & 0.548 & 0.950 & 0.429 & 0.950 & 0.526 & 0.750 \\
\hline
\end{tabular}

Further, based on the grey possibility-degree between compared precautions as alternative set $\mathrm{S}$ $=\left[S_{1}, S_{2}, \ldots ., S_{m}\right]$ and ideal referential precautionary measure (alternative) $S^{\text {max }}$, the ranking of alternatives was done (Table 8 ).

Table 8. $\mathbf{P}\left[S_{i} \leq S^{\max }\right]$ and ranking of precautions (alternatives)

\begin{tabular}{|l|l|l|l|l|l|l|}
\hline $\begin{array}{l}\text { Precautionary- } \\
\text { measures }\end{array}$ & $\mathbf{C}_{\text {EV }}$ & $\mathbf{C}_{\text {So }}$ & $\mathbf{C}_{\mathbf{E C}}$ & SUM & $\begin{array}{l}\text { Grey } \\
\text { possibility- } \\
\text { degree }\end{array}$ & Rank \\
\hline $\mathrm{P}_{1}$ & 0.750 & 1 & 0.877 & 2.627 & 0.657 & 6 \\
\hline $\mathrm{P}_{2}$ & 0.613 & 1 & 0.936 & 2.550 & 0.637 & 5 \\
\hline $\mathrm{P}_{3}$ & 0.571 & 0.798 & 0.820 & 2.189 & 0.547 & 4 \\
\hline $\mathrm{P}_{4}$ & 0.500 & 0.500 & 0.877 & 1.877 & 0.469 & 3 \\
\hline $\mathrm{P}_{5}$ & 0.500 & 0.624 & 0.576 & 1.700 & 0.425 & 2 \\
\hline $\mathrm{P}_{6}$ & 0.654 & 0.500 & 0.500 & 1.654 & 0.414 & 1 \\
\hline
\end{tabular}


Figure 2. The order of importance in public-health precautions against COVID-19

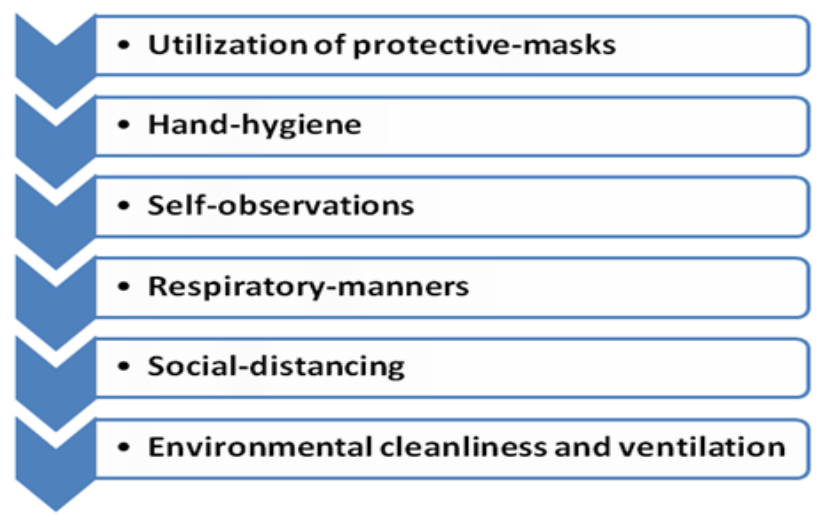

It was found from the ranking (Table 8 ) that the precautionary measures requiring major attention in order to reduce the coronavirus transmission in the population of Indian public included "Utilization of protective-masks" that ranked in the first level followed by "Hand-hygiene", "Self-observations", "Respiratory-manners", "Social-distancing", and "Environmental cleanliness and ventilation", respectively (Figure 2).

\section{CONCLUSION}

For the well-being of public as well as their health conditions, it becomes essential for successfully implementing the primary precautionary-measures with sufficient, clearer as well as consistent information regarding "COVID-19". There has been a higher requirement of proper conveyance of the measures for the betterment of public-health in addition to appropriate recommendation to minimize the transmission of any kind of harmful virus. In the strategies of public-health improvement, reductions in burdens on healthcare systems as well as effective transmission prevention measures need to be incorporated. The spreading of coronavirus being taking place at a rapid rate throughout the world, so the responsibility lies among all individuals, service-providers, policy and decision-makers for proactive-acts in preparing any suitable framework to such an emergency situation.

This study aimed at the promotion and support in adopting in addition to implementation of measures for public-health at both individual \& community levels for the probable reduction of the transmission of coronavirus in Indian scenario. With the use of "Grey-TOPSIS" method, it was found that the precautionary-measures requiring higher attentions by both public and competent authorities were "Utilization of protective-masks" that leaded all other parameters as precautionary-measures in the descending order of "Hand-hygiene", "Self-observations", "Respiratory-manners", "Socialdistancing", and "Environmental cleanliness and ventilation", respectively.

Moreover, for the requirement for effective responses through behavioural-changes, it becomes most important during such an emergency situation to have public-health interventions at all levels. The findings of this analysis will enable in establishing adequate safety measures not only at the individual levels, but also for the entire community groups, service providers, and policy \& decision makers to be well-prepared sufficiently in fighting against "the killer-virus like coronavirus" for ensuring of a sustainable healthy environment in India. 


\section{REFERENCES}

Adl, A., \& Elfergany, A. K. (2020). Tracking How a Change in a Telecom Service Affects Its Customers Using Sentiment Analysis and Personality Insight. International Journal of Service Science, Management, Engineering, and Technology, 11(3), 33-46. doi:10.4018/IJSSMET.2020070103

Aliakbarzadeh, A., \& Tabriz, A. A. (2014). Performance Evaluation and Ranking the Branches of Bank using FAHP and TOPSIS. International Journal of Academic Research in Business \& Social Sciences, 4(12), 199-217. doi:10.6007/IJARBSS/v4-i12/1339

Barhoun, R., Ed-daibouni, M., \& Namir, A. (2019). An Extended Attribute-Based Access Control (ABAC) Model for Distributed Collaborative Healthcare System. International Journal of Service Science, Management, Engineering, and Technology, 10(4), 81-94. doi:10.4018/IJSSMET.2019100105

Chaharsooghi, S. K., \& Ashrafi, M. (2014). Sustainable Supplier Performance Evaluation and Selection with Neofuzzy TOPSIS Method. International Scholarly Notices, 2014, 1-10. doi:10.1155/2014/434168 PMID:27379267

Chawla, R., Sharma, R. K., Madaan, D., Dubey, N., Arora, R., Goel, R., Singh, S., Kaushik, V., Singh, P. K., Chabbra, V., \& Bhardwaj, J. R. (2009). Mitigation approaches to combat the ñu pandemic. Journal of Global Infectious Diseases, 1(2), 117-130. doi:10.4103/0974-777X.56258 PMID:20300402

Chen, P. (2019). A Novel Coordinated TOPSIS Based on Coefficient of Variation. Mathematics, 7(7), 614. doi:10.3390/math7070614

Chen, T.-M., Rui, J., Wang, Q.-P., Zhao, Z.-Y., Cui, J.-A., \& Yin, L. (2020). A mathematical model for simulating the phase-based transmissibility of a novel coronavirus. Infectious Diseases of Poverty, 9(1), 24. doi:10.1186/ s40249-020-00640-3 PMID:32111262

de Souza, G. A. P., Queiroz, V. F., Lima, M. T., de Sousa Reis, E. V., Coelho, L. F. L., \& Abrahão, J. S. (2020). Virus goes viral: An educational kit for virology classes. Virology Journal, 17(1), 13. doi:10.1186/s12985-0201291-9 PMID:32005257

Fatma, L., Ghabi, J., \& Dhouibi, H. (2020). Applying Interval Fuzzy Petri Net to Failure Analysis. International Journal of Service Science, Management, Engineering, and Technology, 11(1), 14-30. doi:10.4018/ IJSSMET.2020010102

Fisher, D., \& Heymann, D. (2020). Q\&A: The novel coronavirus outbreak causing COVID-19. BMC Medicine, 18(1), 57. doi:10.1186/s12916-020-01533-w PMID:32106852

Galli, B. J. (2020a). Economic Decision-Making in Private Corporations Versus Public Sector: How to Compare Both Sectors. International Journal of Service Science, Management, Engineering, and Technology, 11(1), 73-98. doi:10.4018/IJSSMET.2020010106

Galli, B. J. (2020b). Impact and Role of Motivation Theories in Continuous Improvement Environments: A Reflection of Literature. International Journal of Service Science, Management, Engineering, and Technology, 11(1), 1-13. doi:10.4018/IJSSMET.2020010101

Galli, B. J., \& Battiloro, G. (2019). Economic Decision-Making and the Impact of Risk Management: How They Relate to Each Other. International Journal of Service Science, Management, Engineering, and Technology, 10(3), 1-13. doi:10.4018/IJSSMET.2019070101

Gudi, S. K., \& Tiwari, K. K. (2020). Preparedness and lessons learned from the novel coronavirus disease. The International Journal of Occupational and Environmental Medicine, 11(2), 108-112. doi:10.34172/ ijoem.2020.1977 PMID:32218558

Harrison, C. (2020). Coronavirus puts drugrepurposing on the fast track. Nature Biotechnology, 2020(4), 379-381. Advance online publication. doi:10.1038/d41587-020-00003-1 PMID:32205870

Hierlihy, C., Waddell, L., Young, I., Greig, J., Corrin, T., \& Mascarenhas, M. (2019). A systematic review of individual and community mitigation measures for prevention and control of chikungunya virus. PLoS One, 14(2), e0212054. doi:10.1371/journal.pone.0212054 PMID:30811438 
Hui, D. S. C., \& Zumla, A. (2019). Severe acute respiratory syndrome: Historical, epidemiologic, and clinical features. Infectious Disease Clinics of North America, 33(4), 869-889. doi:10.1016/j.idc.2019.07.001 PMID:31668196

Jadidi, O., Yusuff, R. M., Firouzi, F., \& Hong, T. S. (2008). Improvement of a Grey Based Method for supplier selection problem. Journal of Achievement in Materials and Manufacturing Engineering, 31(2), 770-777.

Kuo, Y., Yang, T., \& Huang, G. W. (2008). The use of grey relational analysis in solving multiple attribute decision-making problems. Computers \& Industrial Engineering, 55(1), 80-93. doi:10.1016/j.cie.2007.12.002

Lai, T. H. T., Tang, E. W. H., Chau, S. K. Y., Fung, K. S. C., \& Li, K. K. W. (2020). Stepping up infection control measures in ophthalmology during the novel coronavirus outbreak: An experience from Hong Kong. Graefes Archive for Clinical and Experimental Ophthalmology, 258(5), 1049-1055. Advance online publication. doi:10.1007/s00417-020-04641-8 PMID:32124000

Li, G. D., Yamaguchi, D., \& Nagai, M. (2007). A grey-based decision-making approach to the supplier selection problem. Mathematical and Computer Modelling, 46(3-4), 573-581. doi:10.1016/j.mcm.2006.11.021

Li, G. D., Yamaguchi, D., \& Nagai, M. (2006). A grey-based approach to suppliers selection problem. Proc Int Conf on Parallel, Distributed Processing Techniques and Applications, 180-186.

Li, Y., Bai, W., \& Hashikawa, T. (2020). The neuroinvasive potential of SARS-CoV2 may be at least partially responsible for the respiratory failure of COVID-19 patients. Journal of Medical Virology, 2020. Advance online publication. doi:10.1002/jmv.25728 PMID:32104915

Li, Y., Li, H., Fan, R., Wen, B., Zhang, J., Cao, X., Wang, C., Song, Z., Li, S., Li, X., Lv, X., Qu, X., Huang, R., \& Liu, W. (2016). Coronavirus Infections in the Central Nervous System and Respiratory Tract Show Distinct Features in Hospitalized Children. Intervirology, 59(3), 163-169. doi:10.1159/000453066 PMID:28103598

Mishra, S., Datta, S., \& Mahapatra, S. S. (2013). Grey-based and fuzzy TOPSIS decision-making approach for agility evaluation of mass customization systems. Benchmarking, 20(4), 440-462. doi:10.1108/BIJ-07-2011-0050

Nyaoga, R., Magutu, P., \& Wang, M. (2016). Application of Grey-TOPSIS approach to evaluate value chain performance of tea processing chains. Decision Science Letters, 5, 431-446. doi:10.5267/j.dsl.2016.1.002

Park, J.-E., Jung, S., Kim, A., \& Park, J.-E. (2018). MERS transmission and risk factors: A systematic review. BMC Public Health, 18(1), 574. doi:10.1186/s12889-018-5484-8 PMID:29716568

Peng, X., Xu, X., Li, Y., Cheng, L., Zhou, X., \& Ren, B. (2020). Transmission routes of 2019-nCoV and controls in dental practice. International Journal of Oral Science, 12(1), 9. doi:10.1038/s41368-020-0075-9 PMID:32127517

Rahpeyma, B., \& Zarei, M. (2018). An Integrated QFD-TOPSIS Approach for Supplier Selection Under Fuzzy Environment: A Case of Detergent Manufacturing Industry. International Journal of Service Science, Management, Engineering, and Technology, 9(3), 62-81. doi:10.4018/IJSSMET.2018070105

Roghanian, E., Sheykhan, A., \& Sayyad Abendankashi, E. (2014). An application of fuzzy TOPSIS to improve the process of supply chain management in the food industries: A case study of protein products manufacturing company. Decision Science Letters, 3(1), 17-26. doi:10.5267/j.dsl.2013.10.001

Salamatbakhsh, M., Mobaraki, K., Sadeghimohammadi, S., \& Ahmadzadeh, J. (2019). The global burden of premature mortality due to the Middle East respiratory syndrome (MERS) using standard expected years of life lost, 2012 to 2019. BMC Public Health, 19(1), 1523. doi:10.1186/s12889-019-7899-2 PMID:31727042

Schoeman, D., \& Fielding, B. C. (2019). Coronavirus envelope protein: Current knowledge. Virology Journal, 16(1), 69. doi:10.1186/s12985-019-1182-0 PMID:31133031

Shih, H. S., Shyur, H. J., \& Lee, E. S. (2007). An extension of TOPSIS for group decision making. Mathematical and Computer Modelling, 45(7-8), 801-813. doi:10.1016/j.mcm.2006.03.023

Sisodia, S., \& Agrawal, N. (2019). Examining Employability Skills for Healthcare Services in India: A Descriptive Literature Review. International Journal of Service Science, Management, Engineering, and Technology, 10(3), 63-79. doi:10.4018/IJSSMET.2019070105

Srivastawa, A., Maity, S. R., \& Pandey, K. M. (2017). Material Selection of Gear using Grey TOPSIS and COPRAS-G Method. International Journal of Biotechnology and Biomedical Sciences, 3(1), 34-38. 
Sun, P., Qie, S., Liu, Z., Ren, J., \& Xi, J. J. (2020). Clinical characteristics of 50466 patients with 2019-nCoV infection. medRxiv. 2020. 10.1101/2020.02.18.20024539

Wacharapluesadee, S., Duengkae, P., Chaiyes, A., Kaewpom, T., Rodpan, A., Yingsakmongkon, S., Petcharat, S., Phengsakul, P., Maneeorn, P., \& Hemachudha, T. (2018). Longitudinal study of age-specific pattern of coronavirus infection in Lyle's flying fox (Pteropuslylei) in Thailand. Virology Journal, 15(1), 38. doi:10.1186/ s12985-018-0950-6 PMID:29463282

WHO. (2020a). Report of the WHO-China joint mission on coronavirus disease 2019 (COVID-19). Geneva: WHO. Available from: https://www.who.int/docs/default-source/coronaviruse/who-china-joint-mission-oncovid-19-final-report.pdf

WHO. (2020b). Clinical management of severe acute respiratory infection when novel coronavirus ( $n$ CoV) infection is suspected. Geneva: WHO. Available from: https://www.who.int/publications-detail/clinicalmanagement-of-severe-acute-respiratory-infection-when-novel-coronavirus-(ncov)infection-is-suspected

Wu, F., Zhao, S., Yu, B., Chen, Y.-M., Wang, W., Song, Z.-G., Hu, Y., Tao, Z.-W., Tian, J.-H., Pei, Y.-Y., Yuan, M.-L., Zhang, Y.-L., Dai, F.-H., Liu, Y., Wang, Q.-M., Zheng, J.-J., Xu, L., Holmesm, E. C., \& Zhang, Y.-Z. (2020). A new coronavirus associated with human respiratory disease in China. Nature, 579(7798), $265-284$. doi:10.1038/s41586-020-2008-3 PMID:32015508

Wu, M. (2007). TOPSIS-AHP simulation model and its application to supply chain management. World Journal of Modelling and Simulation, 3(3), 196-201.

Zhang, J., Wu, D., \& Olson, D. L. (2005). The method of grey related analysis to multiple attribute decision making problems with interval numbers. Mathematical and Computer Modelling, 42(9-10), 991-998. doi:10.1016/j. mcm.2005.03.003

Zhou, Y., Hou, Y., Shen, J., Huang, Y., Martin, W., \& Cheng, F. (2020). William Martin and Feixiong Cheng, Network-based drug repurposing for novel coronavirus 2019-nCoV/SARS-CoV-2. Cell Discovery, 6(1), 14. doi:10.1038/s41421-020-0153-3

Debesh Mishra is presently working as assistant professor in SAGE University Bhopal, India and he has more than 25 research publications in different journals and conferences of repute.

V. K. Jain is the Vice Chancellor of SAGE University Bhopal (India) and has more than 25 years of experience in academics. He has more than 200 research publications including Journals, Conferences and Books, Monographs, case studies etc of international repute.

S. Satapathy is associate professor in mechanical engineering having more than 50 publications. 